\title{
Comparative Analysis of Egg Biochemical Composition and Egg Productivity Rainbow Trout (Oncorhynchus mykiss Walbaum, 1792) in Different Stations in Turkey
}

\author{
Birol Baki $^{1, *} \oplus^{\mathbb{D}}$, Dilara Kaya Ozturk ${ }^{1}\left(\mathbb{D}\right.$, Serhat Tomgisi ${ }^{2}$ \\ ${ }^{1}$ Sinop University, Faculty of Fisheries and Aquatic Science, Department of Aquaculture, Sinop, Turkey. \\ ${ }^{2}$ Muğla Sıtkı Kocaman University, Faculty of Fisheries, Muğla, Turkey.
}

How to cite

Baki, B., Kaya Ozturk, D., Tomgisi, S. (2021). Comparatıve Analysis of Egg Biochemical Composition and Egg Productivity Rainbow Trout (Oncorhynchus mykiss Walbaum, 1792) in Different Stations in Turkey. Aquaculture Studies, 21, 117-127. http://doi.org/10.4194/2618-6381-

\section{Article History}

Received 27 August 2020

Accepted 17 March 2021

First Online 23 March 2021

\section{Corresponding Author}

Tel.: +903682876254 - 3104

E-mail: birolbaki@hotmail.com

\section{Keywords}

Oncorhynchus mykiss

Fatty acid

Amino acid

Egg productivity

Egg quality

\begin{abstract}
In the study, two objectives were selected in determining the quality and efficiency of Oncorhynchus mykiss eggs obtained from different stations: (1) to determine the biochemical, amino and fatty acid composition and egg quality, (2) to study the effect of egg productivity on egg quality. The study was conducted in 5 different production areas which is produces the most rainbow trout eggs in Turkey. Broodstocks over 3 years old were randomly selected from the company. After the egg productivity analysis, biochemical analysis were conducted. The most abundant amino acid in all stations was glutamic acid, followed by leucine, lysine, in that order. Total amino acid and essential amino acid (EAA) values were between $30.40 \pm 0.93-44.47 \pm 0.43$ and $15.69 \pm 0.25-23.88 \pm 0.07 \mathrm{~g} / 100 \mathrm{~g}$, respectively. As a result of analysis of fatty acids, docosahexaenoic acid (DHA), oleic acid and linoleic acid values were higher than other fatty acids. In addition, polyunsaturated (PUFA) values were higher than saturated (SFA) and monounsaturated (MUFA) fatty acid values in the eggs obtained from all stations. Consequently, the amino and fatty acid values of rainbow trout eggs were determined to be sufficient for embryonic development of fish and this values showed rainbow trout eggs as potential source of food for human consumption.
\end{abstract}

\section{Introduction}

In aquaculture, egg quality is important for the production of healthy and high quality fish larvae and in terms of economic utilization of hatcheries. During embryogenesis periods of most fish species, growth and energy procure are dependent yolk reserves transplanted by broodstocks. As a rule, fish eggs contain all the nutrients that the larvae utilize during to support both homeostasis and development (Mourente \& Vazquez, 1996). It reported that the biochemical composition of fish eggs is species-specific, and the precise sequence of consumption (proteins, lipids and carbohydrates) varies both qualitatively and quantitatively (Cejas et al. 2004; Sargent, Henderson \& Tocher, 1989). While embryos of turbot (Scophthalmus maximus) catabolize exclusively proteins and carbohydrates (Planas et al. 1993), whereas embryos of rainbow trout (Oncorhynchus mykiss Walbaum, 1792) use proteins, lipids and carbohydrates to satisfy their energy requirements (Boulekbache, 1981).

In rainbow trout farming, egg quality is important as well as harvest fish quality. During the production period, broodstocks productivity and egg quality are effective in high values such as growth and feed evaluation performance and survival rate. Because egg quality parameters play a significant role in fertilization of the egg, embryonic development and the larval survival rate, under appropriate conditions.

The biochemical composition of eggs is one of the factors determining egg quality since eggs must contain all the nutrients required for normal development 
during embryonic stages. Several morphological (Kjorsvik, Mangor Jensen \& Holmefjord, 1990, Thorsen, Trippel \& Lambert, 2003) and biochemical parameters such as lipids (Sargent, 1995, Bell \& Sargent, 2003, Tveiten, Jobling \& Andreasen, 2004), amino acids (Ronnestad \& Fyhn, 1993) or vitamins (Ronnestad, Lie \&Waagbo, 1997, Maeland, Ronnestad, \& Waagbo, 2003) have been considered as indicators of egg quality (Gimenez et al. 2006). Apart from this, several nutrients such as amino acids, vitamins and essential fatty acids have been suggested to be related to egg quality in both freshwater and marine fishes (Takeuchi, Ishii \& Ogiso, 1981; Watanabe \& Kiron, 1985). On the purpose of obtaining an optimal level of each nutrient in eggs, it is necessary to feed broodstock with diets having an optimal composition since egg nutrient contents reflect the broodstock nutritional status (Watanabe et al. 1984; Furuita, Tanaka, Yamamoto, Suziki \& Takeuchi, 2002, Furuita et al. 2003). However, few is known about the interaction between egg quality and egg biochemical composition rainbow trout. More information on the relationship between egg composition and egg quality is needed for the improvement of egg quality. For this purpose, in the present study was to highlight the efficiency of rainbow trout eggs at different stations and the quality of eggs with their biochemical, amino acid and fatty acid composition. Two objectives were selected: (1) to determine the biochemical, amino acid and fatty acid composition of rainbow trout eggs and egg quality, (2) to study the effect of egg productivity on egg quality.

\section{Materials and Methods}

\section{Study Design}

The study was conducted in 5 different production areas (I station: $36^{\circ} 45^{\prime} 59.55^{\prime \prime} \mathrm{N}$ and $29^{\circ} 24^{\prime} 12.22^{\prime \prime} \mathrm{E}$ Muğla-Fethiye; II station: $36^{\circ} 58^{\prime} 41.94^{\prime \prime} \mathrm{N}$ and $29^{\circ} 13^{\prime} 9.92$ "E Denizli-Çameli; III station: 3857'54.89"N 36 40'18.17"E Kayseri-Pınarbaşı; IV station: $37^{\circ} 58^{\prime} 58.65^{\prime \prime} \mathrm{N}$ and $38^{\circ} 0^{\prime} 52.89^{\prime \prime} \mathrm{E}$ Malatya-Sürgü and $\mathrm{V}$ station: $41^{\circ} 27^{\prime} 14.35^{\prime \prime} \mathrm{N}$ and $35^{\circ} 51^{\prime} 24.08^{\prime \prime E}$ SamsunLadik) which is produces the most rainbow trout eggs in Turkey from December 2017 to January 2018. Water temperature were measured from each production areas during milking.

\section{Brootstock Characteristics and Milking}

In this study, broodstocks over 3 years old were used. When selecting broodstocks were paid attention to non-abnormality appearance, disease-free, active movement and healthy individuals. Brootstocks were randomly sampled by business employee. Fort his reason, this manuscript does not need an ethical approval. Biometric measurements (weight-length) of the broodstocks were made before milking. Weight measurements of the fishes were made with $\pm 5 \mathrm{~g}$ precision electronic balance. Before milking, fish were dried with a towel to prevent slipping. Milking process was carried out by holding the tail and head of broodstocks slowly caressing the abdomen from the chest to the tail. The maturated eggs that spilled from the urogenital cavity of the fish were collected in a plastic container.

\section{Brootstock-Egg Productivity Analysis}

Eggs were randomly sampled from plastic containers with 3 replicates and eggs count, weight and diameter were measured immediately after milking process. Absolute egg productivity (AEP, pieces/fish) was calculated according to the weight method by counting $10 \mathrm{~g}$ eggs after weighing the total egg weight. The relative egg productivity (REP, pieces/ $\mathrm{kg}$ ) was calculated as the ratio of the total number of eggs to the weight of the brootstock. Egg diameter was measured by random sampling method using 100 pieces and average egg diameter $(\mathrm{mm})$ was determined. Egg productivity analysis was performed with 3 replications.

Egg samples were stored in a deep freezer (WiseCryo/WUF-D $500-80^{\circ} \mathrm{C}$ ) until analysis, and transportation of samples to the laboratory was provided by cold chain conditions.

\section{Biochemical, Amino and Fatty Acids Composition Analysis}

Analysis of dry matter (DM) and crude ash (CA) in the eggs was performed according to standard AOAC (1995) procedures in the laboratory of Aquaculture, Faculty of Fisheries. Eggs crude lipids (CF) were determined according to the procedure of Soxhlet methods. Crude protein (CP) content was determined as total nitrogen content by Kjeldahl method (AOAC, 1995).

Amino acid analysis of eggs was performed using the Jasem LC-MS/MS amino acid assay kit. The concentration of the target amino acids was determined using the electrospray ionization (ESI)-based multiple reaction monitoring (MRM) mode. $0.5 \mathrm{~g}$ sample was taken into a glass vial with a screw cap, and $4 \mathrm{ml}$ of reagent- 2 was added, and then, hydrolysis reaction was performed at $110^{\circ} \mathrm{C}$ for $24 \mathrm{hr}$. The hydrolysate was centrifuged for $5 \mathrm{~min}$ at $4000 \mathrm{rpm}$ when it reached room temperature. Then, $100 \mu \mathrm{l}$ of the supernatant was transferred to a vial and completed to $1 \mathrm{ml}$ with distilled water. This dilution procedure was repeated one more time to yield 800 -fold diluted hydrolysate of the sample. $50 \mu \mathrm{l}$ of the diluted hydrolysate was transferred to a sample vial and $50 \mu \mathrm{l}$ of internal standard mixture with isotope labelled and $700 \mu$ l of reagent- 1 was added, respectively, and then, the mixture was vortexed for $5 \mathrm{~s}$. All samples were prepared according to the above procedures and injected into the LC-MS/MS system where theamounts of amino acids were read.

The total amino acids and quality of amino acids were calculated from the following formulas: 
Essential Amino Acids $(E A A)=$ Histidine + Lysine + Phenylalanine + Methionine + Threonine + Leucine + Isoleucine + Valine + Arginine

Semi-Essential Amino Acids (SEAA) =Histidine + Arginine

Non-Essential Amino Acids (NEAA)=Alanine + Aspartic acid + Glutamic acid + Tyrosine + Glycine + Serine + Proline

Branched-chain amino acid $(B c A A)=$ Leucine + Isoleucine + Valine

Sulphur-containing amino acids $(\mathrm{SAA})=$ Cystine + Methionine

Aromatic amino acids $($ ArAA $)=$ Phenylalanine + Tyrosine

Basic (alkaline) amino acids (BAA)=Lysine + Arginine + Histidine

Acidic amino acids $(A A A)=$ Aspartic acid + Glutamic acid

The samples were converted to methyl esters by derivatization of lipid samples in gas chromatography device (Thermo Scientific Trace 1310) for fatty acid analyses. For this purpose, $0.25 \mathrm{~g}$ of the extracted oil was removed and $4 \mathrm{ml}$ of heptane and $0.4 \mathrm{ml}$ of $2 \mathrm{~N} \mathrm{KOH}$ were added. The mixture was stirred in a vortex for 2 $\mathrm{min}$, and then centrifuged at $5000 \mathrm{rpm}$ for $5 \mathrm{~min}$. After centrifugation, $1.5-2 \mathrm{ml}$ of the heptane phase was collected and transferred to glass tubes for GC/MS analysis. Injection of samples into the device was carried out with an automatic sampler (Autosampler Al 1310). Samples were analysed by Thermo Scientific ISQ LT model GC/MS. For this analysis, Trace Gold TG-WaxMS capillary column (Thermo Scientific code: 26088-1540) with a film thickness of $0.25 \mu \mathrm{m}$ and $60 \mathrm{~m}$ length was used. The injection block temperature was set to $240^{\circ} \mathrm{C}$, and the column temperature was increased from $100^{\circ} \mathrm{C}$ to $240^{\circ} \mathrm{C}$ in the temperature programme. Helium gas ( 1 $\mathrm{ml} / \mathrm{min}$ ) was used as a carrier gas at constant flow, and 1:20 split ratio was applied. The MS unit (ISQ LT) was used in electron ionization mode. Fatty acids were defined by comparing the standard FAME mixture of 37 components based on the arrival times.

The total fatty acids and quality of fatty acids were calculated from the following formulas:

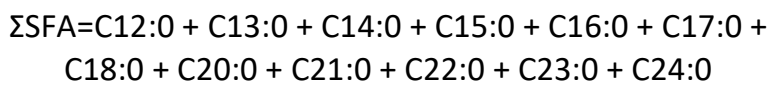

IMUFA $=\mathrm{C} 14: 1+\mathrm{C} 15: 1+\mathrm{C} 16: 1+\mathrm{C} 17: 1+\mathrm{C} 18: 1 \mathrm{n}-9 \mathrm{c}+$ C18:1n-9t + C20:1n-9c + C22:1n-9 + C24:1

IPUFA $=\mathrm{C} 18: 2 \mathrm{n}-6 \mathrm{t}+\mathrm{C} 18: 2 \mathrm{n}-6 \mathrm{c}+\mathrm{C} 18: 3 \mathrm{n}-3+\mathrm{C} 18: 3 \mathrm{n}-6+$ $\mathrm{C} 20: 2+\mathrm{C} 22: 2+\mathrm{C} 20: 3 n-6+\mathrm{C} 20: 5 n-3+\mathrm{C} 20: 4 n-6+$ C22:6n-3

\author{
LOmega-3 $($ (ه) $=C 18: 3 n-3+C 20: 3 n-3+C 20: 5 n-3+$ \\ $C 22: 5 n-3+C 22: 6 n-3$
}

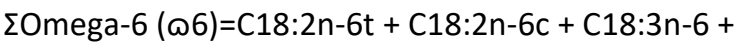 C20:4n-6+C20:3n-6
LOmega-9 (ه9)=C18:1n-9c + C18:1n-9t + C20:1n-9c + C22:1n-9

Index atherogenicity $(\mathrm{IA})=[(\mathrm{C} 12: 0+(4 \times \mathrm{C} 14: 0)+\mathrm{C} 16: 0)]$ / (MUFA + Omega-3 + Omega-6)

Index thrombogenicity (IT) $=(\mathrm{C} 14: 0+\mathrm{C} 16: 0+\mathrm{C} 18: 0) /$ $[(0.5 \times$ MUFA $)+(0.5 \times$ Omega -6$)+(3 \times$ Omega -3$)+$ (Omega-3 / Omega-6)]

Hypocholesterolaemic/hypercholesterolaemic ratio $(H H)=(C 18: 1 n-9+C 18: 2 n-6+C 18: 3 n-3+C 20: 4 n-6+$ $C 20: 5 n-3+C 22: 6 n-3) /(C 14: 0+C 16: 0)$

\section{Statistical Analysis}

All analyses results were presented as mean values \pm SE. Statistical analysis was done by using the IBM SPSS 21 statistical package program (IBM Corp. in Armonk, NY). The differences between the results were tested by one-way analysis of variance (ANOVA). The Tukey test was used for comparisons since the equality of the samples. The relationships between the values were tested by correlation analyses.

\section{Result}

Water temperatures in different production areas were between $11.5-13^{\circ} \mathrm{C}$ (average $12.25 \pm 0.53^{\circ} \mathrm{C}$ ), 7.5- $8^{\circ} \mathrm{C}$ (average $7.75 \pm 0.18^{\circ} \mathrm{C}$ ); $9-10^{\circ} \mathrm{C}$ (average $9.50 \pm 0.35^{\circ} \mathrm{C}$ ); $7.5-11.5^{\circ} \mathrm{C}$ (average $9.50 \pm 1.41^{\circ} \mathrm{C}$ ) and 4- $7^{\circ} \mathrm{C}$ (average $5.50 \pm 1.06^{\circ} \mathrm{C}$ ), respectively.

In the study, weight and length values of broodstocks, diameter and weight values of eggs, absolute egg productivity (AEP) and relative egg productivity (REP) are given in Table 1 . In the study, while the highest average broodstock weight was in the 3 rd station, the lowest average broodstock weights were in the 1 st and 2 nd stations.

In the study, the correlation matrix of broodstock weight (BW), egg diameter (ED), egg weight (EG) and productivity (AEP and REP) are given in Table 2. As a result of the correlation analysis, while the broodstock weight and egg diameter and weight increased, absolute and relative egg yield values decreased. While egg weight and egg diameter were increasing, absolute and relative egg productivity decreased.

The proximate composition of egg samples in all station are given in Table 3 . In the study, the crude protein (CP), crude lipid (CL), crude ash (CA) and dry matter (DM) values of all the sampled eggs were between $20.60 \pm 0.80-25.43 \pm 0.50,3.19 \pm 0.18-5.76 \pm 0.14$, $3.87 \pm 0.55-4.52 \pm 0.02$ and $34.97 \pm 0.09-40.50 \pm 0.08 \%$, 
Table 1. Broodstocks weight, height, egg diameter (ED) and weight (EW) and absolute egg productivity (AEP) and relative egg productivity (REP) values for different production areas

\begin{tabular}{|c|c|c|c|c|c|c|}
\hline & & I. Station & II.Station & III.Station & IV.Station & V.Station \\
\hline \multirow{2}{*}{ 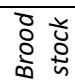 } & Weight (g) & $1522.00 \pm 80.80^{\mathrm{a}}$ & $1445.50 \pm 46.10^{\mathrm{a}}$ & $2171.00 \pm 145.20^{b}$ & $3612.00 \pm 230.50^{c}$ & $1745.00 \pm 89.40^{\mathrm{ab}}$ \\
\hline & Length $(\mathrm{cm})$ & $47.45 \pm 0.63^{a}$ & $47.57 \pm 0.89^{a}$ & $52.35 \pm 1.47^{b}$ & $64.58 \pm 1.32^{c}$ & $51.00 \pm 1.10^{\mathrm{ab}}$ \\
\hline & Diameter $(\mathrm{mm})$ & $4.05 \pm 0.07^{a}$ & $3.99 \pm 0.05^{a}$ & $4.61 \pm 0.04 b$ & $4.92 \pm 0.07^{c}$ & $4.20 \pm 0.06^{\mathrm{a}}$ \\
\hline & Weight (mg) & $50.56 \pm 4.00^{a}$ & $49.40 \pm 1.97^{a}$ & $86.90 \pm 3.96^{b}$ & $98.76 \pm 5.93^{c}$ & $52.01 \pm 1.70^{\mathrm{a}}$ \\
\hline \multicolumn{2}{|c|}{ AEP (pieces/fish) } & $3606 \pm 568^{c}$ & $1181 \pm 157^{a}$ & $2062 \pm 82^{b}$ & $1916 \pm 179^{a b}$ & $2640 \pm 287^{b c}$ \\
\hline \multicolumn{2}{|c|}{ REP (pieces $/ \mathrm{kg})$} & $2121.20 \pm 272.33^{c}$ & $356.81 \pm 72.11^{\mathrm{a}}$ & $1451.68 \pm 96.14^{c}$ & $932.39 \pm 114.99^{b}$ & $1756.60 \pm 180.64^{c}$ \\
\hline
\end{tabular}

Values in same rows marked with different letters are significantly different $(\mathrm{P}<0.05)$.

Table 2. Correlation matrix of broodstock weight (BW), egg diameter (ED), egg weight (EG) and productivity (AEP and REP)

\begin{tabular}{lccccc}
\hline & $B W$ & $E D$ & $E W$ & $A E P$ & $R E P$ \\
\hline$B W$ & $*$ & $<0.01$ & $<0.01$ & $<0.01$ & $<0.01$ \\
$E D$ & 0.818 & $*$ & $<0.01$ & $<0.01$ & $<0.01$ \\
$E D$ & 0.795 & 0.887 & $*$ & $<0.01$ & $<0.01$ \\
$A E P$ & -0.562 & -0.622 & -0.719 & $*$ & $<0.01$ \\
$R E P$ & -0.776 & -0.801 & -0.833 & 0.951 & $*$ \\
\hline
\end{tabular}

Table 3. Proximate compositions of eggs of rainbow trout in belonging to different stations

\begin{tabular}{lccccc}
\hline Proximate compositions & I.Station & II.Station & III.Station & IV.Station & V.Station \\
\hline Crude Protein, \% & $22.07 \pm 0.55^{\mathrm{a}}$ & $22.54 \pm 0.53^{\mathrm{ab}}$ & $23.57 \pm 0.28^{\mathrm{ab}}$ & $20.60 \pm 0.80^{\mathrm{a}}$ & $25.43 \pm 0.50^{\mathrm{b}}$ \\
Crude Lipid, \% & $3.19 \pm 0.18^{\mathrm{a}}$ & $3.50 \pm 0.03^{\mathrm{ab}}$ & $5.76 \pm 0.14^{\mathrm{c}}$ & $5.63 \pm 0.35^{\mathrm{c}}$ & $4.57 \pm 0.21^{\mathrm{bc}}$ \\
Crude Ash, \% & $3.87 \pm 0.55^{\mathrm{a}}$ & $4.17 \pm 0.22^{\mathrm{a}}$ & $4.52 \pm 0.02^{\mathrm{a}}$ & $4.50 \pm 0.08^{\mathrm{a}}$ & $4.37 \pm 0.46^{\mathrm{a}}$ \\
Dry Matter, \% & $34.97 \pm 0.09^{\mathrm{a}}$ & $34.99 \pm 0.03^{\mathrm{a}}$ & $37.47 \pm 0.10^{\mathrm{b}}$ & $35.20 \pm 0.28^{\mathrm{a}}$ & $40.50 \pm 0.08^{\mathrm{c}}$ \\
\hline
\end{tabular}

Values in same rows marked with different letters are significantly different $(\mathrm{P}<0.05)$.

respectively and the statistical difference between values were important $(P<0.05)$.

The results of fatty acids in eggs are summarised in Table 4. Of these fatty acids, C16:0, C18:1n-9c, C18:2n$6 c$, and C22:6n-3 were particularly abundant in the eggs of all stations. Monounsaturated fatty acids (MUFA), mainly C18:1n-9, and saturated fatty acids, mainly C16:0, comprised approximately 10 and 13\%, respectively, of the total fatty acids in all station of rainbow trout eggs. The major polyunsaturated fatty acid (PUFA) was docosahexaenoic acid (DHA), which were between $14.94 \pm 1.07$ and $16.65 \pm 0.19 \%$ of the fatty acids in all egg samples and was also the most abundant fatty acid in all station rainbow trout eggs. The fatty-acid composition of rainbow trouts eggs in all stations was dominated by PUFA, predominantly of the $(\omega-3)$ series. ๑-3 PUFA accounted for $23.53 \pm 0.36,24.51 \pm 0.04$, $24.63 \pm 0.05,24.01 \pm 0.96$ and $21.21 \pm 0.28 \%$, respectively, of the total fatty acids in all stations. The ratio of EPA/DHA were the highest in 4th station and the lowest in 1st Station and the statistical difference between values were important $(P<0.05)$. The significant difference among all stations values of index atherogenicity $(I A)$ in rainbow trout eggs $(P<0.05)$. The thrombogenicity index (IT) of eggs in all station were between $0.19 \pm 0.01$ and $0.23 \pm 0.01(P<0.05)$.

As a result of the correlation analysis, the negative relationship was determined between the egg weight and the total saturated fatty acid ( $\Sigma S F A$ ) values of the eggs $(r=-0.771, P=0.127)$. In addition, egg weight and diameter and $\sum$ PUFA values are parallel and there is a strong positive relationship between these values ( $r=0.847, \mathrm{P}=0.070 ; \mathrm{r}=0.843, \mathrm{P}=0.073$ ).

The content of 19 amino acids of rainbow trout egg in all stations are shown in Table 5. As mentioned above, fish eggs are high source of proteins and amino acids. Among essential amino acids (EAA) in present study, the most important contributor was leucine and lysine, and the least important was methionine. A significantly higher EAA content was found in the 5 th station compared to the other stations. Among the nonessential amino acids (NAA), glutamic acid occurred in the highest amount, while the ornithine and taurine content were the lowest. A significantly higher level of NAAs was found in the 5 th station compared to the other stations. It is worth noting that the rainbow trout egg in the 5th station contained significantly more crude protein, which could have affected the results.

According to the results, the total amino acids ( $\mathrm{AA}$ ) were different in all stations and the highest value was in 5th station. $(P<0.05)$. The average values of amino acid quality of rainbow trout eggs in all station were as follows: $5.62 \pm 0.12$ and $8.88 \pm 0.08 \mathrm{~g} / 100 \mathrm{~g}$ Branched-chain amino acid (BcAA), $1.37 \pm 0.02$ and $2.01 \pm 0.04 \mathrm{~g} / 100 \mathrm{~g}$ Sulphur-containing amino acid (SAA), $2.53 \pm 0.07$ and $3.92 \pm 0.10 \mathrm{~g} / 100 \mathrm{~g}$ Aromatic amino acid (ArAA), $5.58 \pm 0.03$ and $8.50 \pm 0.02 \mathrm{~g} / 100 \mathrm{~g}$ Basic (alkaline) amino acid (BAA) and $5.42 \pm 0.04$ and $8.02 \pm 0.03 \mathrm{~g} / 100 \mathrm{~g}$ Acidic amino acid (AAA), respectively and the statistical difference between values were important $(P<0.05)$ (Table 5). 
Table 4. Fatty acid composition of eggs of rainbow trout in belonging to different stations

\begin{tabular}{|c|c|c|c|c|c|}
\hline Fatty Acids & I.Station & II.Station & III.Station & IV.Station & V.Station \\
\hline C12:0 (\%) & $0.03 \pm 0.01^{c}$ & $0.01 \pm 0.01^{\mathrm{a}}$ & $0.02 \pm 0.01^{b}$ & $0.01 \pm 0.01^{\mathrm{a}}$ & $0.02 \pm 0.01^{\mathrm{bc}}$ \\
\hline C13:0 (\%) & $0.02 \pm 0.01^{\mathrm{a}}$ & $0.01 \pm 0.01^{a}$ & $0.01 \pm 0.01^{\mathrm{a}}$ & $0.01 \pm 0.01^{a}$ & $0.02 \pm 0.01^{\mathrm{a}}$ \\
\hline C14:0 (\%) & $1.74 \pm 0.03^{c}$ & $1.52 \pm 0.01^{b}$ & $1.70 \pm 0.01^{c}$ & $1.34 \pm 0.05^{\mathrm{a}}$ & $1.79 \pm 0.04^{c}$ \\
\hline C15:0 (\%) & $0.48 \pm 0.01^{b c}$ & $0.46 \pm 0.01^{b}$ & $0.54 \pm 0.01^{c d}$ & $0.30 \pm 0.02^{\mathrm{a}}$ & $0.55 \pm 0.02^{d}$ \\
\hline C16:0 (\%) & $10.20 \pm 0.08^{b}$ & $10.22 \pm 0.03^{b}$ & $10.32 \pm 0.01^{b}$ & $9.30 \pm 0.24^{a}$ & $10.24 \pm 0.06^{b}$ \\
\hline C17:0 (\%) & $0.72 \pm 0.02^{c}$ & $0.45 \pm 0.01^{b}$ & $0.45 \pm 0.01^{b}$ & $0.25 \pm 0.02^{a}$ & $0.65 \pm 0.04^{c}$ \\
\hline C18:0 (\%) & $9.07 \pm 0.14^{b}$ & $7.61 \pm 0.02^{\mathrm{a}}$ & $8.00 \pm 0.07^{a}$ & $7.24 \pm 0.36^{\mathrm{a}}$ & $7.50 \pm 0.19^{a}$ \\
\hline C20:0 (\%) & $0.43 \pm 0.01^{a}$ & $0.54 \pm 0.01^{\mathrm{a}}$ & $0.56 \pm 0.01^{\mathrm{a}}$ & $1.65 \pm 0.07^{b}$ & $0.46 \pm 0.02^{\mathrm{a}}$ \\
\hline C21:0 (\%) & $4.53 \pm 0.07^{c}$ & $4.36 \pm 0.01^{c}$ & $3.76 \pm 0.01^{b}$ & $3.32 \pm 0.08^{a}$ & $4.82 \pm 0.07^{d}$ \\
\hline C22:0 (\%) & $4.09 \pm 0.05^{c}$ & $2.67 \pm 0.01^{a}$ & $3.17 \pm 0.02^{b}$ & $3.13 \pm 0.10^{b}$ & $4.17 \pm 0.04^{c}$ \\
\hline C23:0 (\%) & $0.11 \pm 0.01^{\mathrm{ab}}$ & $0.09 \pm 0.01^{a}$ & $0.13 \pm 0.01^{b}$ & $0.11 \pm 0.02^{\mathrm{ab}}$ & $0.10 \pm 0.01^{a}$ \\
\hline C24:O (\%) & $0.36 \pm 0.01^{a}$ & $0.35 \pm 0.01^{a}$ & $0.55 \pm 0.01^{b}$ & $0.51 \pm 0.03^{b}$ & $0.39 \pm 0.02^{\mathrm{a}}$ \\
\hline$\sum S F A(\%)$ & $31.77 \pm 0.33^{c}$ & $28.30 \pm 0.04^{a}$ & $29.22 \pm 0.13^{\mathrm{ab}}$ & $27.16 \pm 0.98^{a}$ & $30.71 \pm 0.36^{b c}$ \\
\hline C14:1 (\%) & $0.14 \pm 0.01^{c}$ & $0.09 \pm 0.01^{b}$ & $0.10 \pm 0.01^{b}$ & $0.06 \pm 0.01^{\mathrm{a}}$ & $0.13 \pm 0.01^{c}$ \\
\hline C15:1 (\%) & $0.09 \pm 0.01^{b}$ & $0.09 \pm 0.01^{b}$ & $0.08 \pm 0.01^{b}$ & $0.05 \pm 0.01^{a}$ & $0.09 \pm 0.01^{b}$ \\
\hline C16:1 (\%) & $4.02 \pm 0.03^{b}$ & $3.78 \pm 0.01^{\mathrm{a}}$ & $4.26 \pm 0.02^{c}$ & $3.78 \pm 0.08^{a}$ & $3.64 \pm 0.02^{\mathrm{a}}$ \\
\hline C17:1 (\%) & $0.55 \pm 0.02^{c}$ & $0.46 \pm 0.01^{b}$ & $0.58 \pm 0.01^{c}$ & $0.36 \pm 0.02^{\mathrm{a}}$ & $0.51 \pm 0.03^{b c}$ \\
\hline C18:1n9c (\%) & $12.69 \pm 0.59^{a}$ & $12.10 \pm 0.02^{\mathrm{a}}$ & $14.45 \pm 0.03^{b}$ & $15.69 \pm 0.34^{b}$ & $12.12 \pm 0.07^{a}$ \\
\hline C18:1n9t (\%) & $3.14 \pm 0.49^{a}$ & $3.70 \pm 0.01^{\mathrm{a}}$ & $3.79 \pm 0.09^{a}$ & $3.45 \pm 0.09^{a}$ & $3.62 \pm 0.92^{\mathrm{a}}$ \\
\hline C20:1n9c (\%) & $3.41 \pm 0.04^{c}$ & $2.50 \pm 0.01^{a}$ & $3.34 \pm 0.01^{c}$ & $3.03 \pm 0.07^{b}$ & $3.12 \pm 0.01^{b}$ \\
\hline C22:1n9 (\%) & $1.01 \pm 0.03^{a}$ & $1.75 \pm 0.01^{b}$ & $1.76 \pm 0.01^{b}$ & $2.12 \pm 0.09^{c}$ & $1.14 \pm 0.05^{\mathrm{a}}$ \\
\hline C24:1 (\%) & $1.52 \pm 0.03^{d}$ & $0.85 \pm 0.01^{b}$ & $0.78 \pm 0.02^{b}$ & $0.54 \pm 0.03^{a}$ & $1.30 \pm 0.04^{c}$ \\
\hline ¿MUFA (\%) & $26.57 \pm 0.80^{\mathrm{a}}$ & $25.32 \pm 0.02^{\mathrm{a}}$ & $29.14 \pm 0.13^{b}$ & $29.08 \pm 0.57^{b}$ & $25.69 \pm 0.10^{\mathrm{a}}$ \\
\hline C18:2n6t (\%) & $0.32 \pm 0.01^{b}$ & $0.21 \pm 0.01^{\mathrm{a}}$ & $0.52 \pm 0.01^{c}$ & $0.46 \pm 0.03^{c}$ & $0.34 \pm 0.02^{b}$ \\
\hline c18:2n6c (\%) & $10.11 \pm 0.14^{b}$ & $11.29 \pm 0.01^{c}$ & $9.37 \pm 0.07^{a}$ & $11.14 \pm 0.16^{c}$ & $11.55 \pm 0.13^{c}$ \\
\hline C18:3n3 (\%) & $0.32 \pm 0.01^{d}$ & $0.16 \pm 0.01^{a}$ & $0.23 \pm 0.01^{b}$ & $0.24 \pm 0.02^{b c}$ & $0.30 \pm 0.02^{c d}$ \\
\hline C18:3n6 (\%) & $2.55 \pm 0.04^{a}$ & $3.23 \pm 0.01^{c}$ & $3.35 \pm 0.05^{c}$ & $3.76 \pm 0.13^{d}$ & $2.97 \pm 0.01^{b}$ \\
\hline C20:2 (\%) & $4.53 \pm 0.07^{c}$ & $4.36 \pm 0.01^{c}$ & $3.76 \pm 0.01^{b}$ & $3.32 \pm 0.08^{a}$ & $4.82 \pm 0.07^{d}$ \\
\hline C20:5n-3 (\%) & $4.33 \pm 0.15^{\mathrm{a}}$ & $5.34 \pm 0.01^{c}$ & $5.31 \pm 0.04^{c}$ & $5.32 \pm 0.04^{c}$ & $4.82 \pm 0.16^{b}$ \\
\hline C20:4n:6 (\%) & ND & $2.67 \pm 0.01^{a}$ & ND & $2.93 \pm 0.01^{b}$ & ND \\
\hline$C 22: 6 n-3(\%)$ & $16.65 \pm 0.19^{a}$ & $15.95 \pm 0.04^{a}$ & $15.97 \pm 0.12^{\mathrm{a}}$ & $14.94 \pm 1.07^{a}$ & $16.10 \pm 0.24^{a}$ \\
\hline$C 22: 2(\%)$ & $0.11 \pm 0.01^{\mathrm{ab}}$ & $0.09 \pm 0.01^{\mathrm{a}}$ & $0.13 \pm 0.01^{b}$ & $0.11 \pm 0.02^{\mathrm{ab}}$ & $0.10 \pm 0.01^{\mathrm{a}}$ \\
\hline ¿PUFA (\%) & $41.64 \pm 0.58^{a}$ & $46.37 \pm 0.05^{b c}$ & $41.63 \pm 0.03^{a}$ & $43.74 \pm 1.56^{\mathrm{ab}}$ & $43.61 \pm 0.32^{\mathrm{ab}}$ \\
\hline ¿Omega-3 (\%) & $23.53 \pm 0.36^{b}$ & $24.51 \pm 0.04^{b}$ & $24.63 \pm 0.05^{b}$ & $24.01 \pm 0.96^{b}$ & $21.21 \pm 0.28^{a}$ \\
\hline somega-6 (\%) & $13.47 \pm 0.16^{a}$ & $17.42 \pm 0.01^{b}$ & $13.11 \pm 0.04^{\mathrm{a}}$ & $16.30 \pm 0.69^{b}$ & $17.48 \pm 0.09^{b}$ \\
\hline sOmega-9 (\%) & $20.25 \pm 0.84^{a}$ & $20.05 \pm 0.02^{\mathrm{a}}$ & $23.34 \pm 0.14^{b}$ & $24.28 \pm 0.43^{b}$ & $20.01 \pm 0.19^{a}$ \\
\hline ๑3/ه6 & $1.74 \pm 0.01^{\mathrm{d}}$ & $1.41 \pm 0.01^{b}$ & $1.88 \pm 0.01^{\mathrm{e}}$ & $1.48 \pm 0.01^{c}$ & $1.21 \pm 0.02^{\mathrm{a}}$ \\
\hline ๑6/ద3 & $0.57 \pm 0.01^{b}$ & $0.71 \pm 0.01^{d}$ & $0.53 \pm 0.01^{a}$ & $0.68 \pm 0.01^{c}$ & $0.82 \pm 0.01^{\mathrm{e}}$ \\
\hline$E P A / D H A$ & $0.26 \pm 0.01^{a}$ & $0.33 \pm 0.01^{b c}$ & $0.33 \pm 0.01^{b c}$ & $0.36 \pm 0.03^{c}$ & $0.30 \pm 0.01^{\mathrm{ab}}$ \\
\hline$D H A / E P A$ & $3.85 \pm 0.09^{d}$ & $2.99 \pm 0.01^{\mathrm{ab}}$ & $3.01 \pm 0.04^{b}$ & $2.81 \pm 0.22^{\mathrm{a}}$ & $3.35 \pm 0.13^{c}$ \\
\hline$A l$ & $0.27 \pm 0.01^{\mathrm{cd}}$ & $0.24 \pm 0.01^{b}$ & $0.26 \pm 0.01^{c}$ & $0.21 \pm 0.01^{\mathrm{a}}$ & $0.28 \pm 0.01^{d}$ \\
\hline $\mathrm{TI}$ & $0.23 \pm 0.01^{c}$ & $0.20 \pm 0.01^{\mathrm{ab}}$ & $0.21 \pm 0.01^{b c}$ & $0.19 \pm 0.01^{a}$ & $0.23 \pm 0.01^{c}$ \\
\hline$H H$ & $3.69 \pm 0.01^{a}$ & $4.05 \pm 0.01^{d}$ & $3.78 \pm 0.01^{b c}$ & $4.58 \pm 1.04^{\mathrm{e}}$ & $3.73 \pm 0.06^{b}$ \\
\hline$E P A+D H A$ & $20.98 \pm 0.34^{b}$ & $21.28 \pm 0.04^{c}$ & $21.26 \pm 0.09^{c}$ & $20.25 \pm 0.28^{a}$ & $20.92 \pm 0.27^{b}$ \\
\hline
\end{tabular}

Values in same rows marked with different letters are significantly different $(\mathrm{P}<0.05)$.

\section{Discussion}

In this study, all production areas have different water temperature values especially during milking periods. In different studies were reported that water temperatures affect gonad development, egg fertilization and hatching efficiency in trout and generally water temperature values should be between $7-10^{\circ} \mathrm{C}$ in egg production (Leitritz \& Lewis, 1980; Aras, 1988; Çelikkale, 1998; Hardy \& Fornshell, 2000). Water temperature values measured in all production areas are in accordance with the literature and were determined to have a negative effect on egg development.

In the study, it was determined all broodstocks have the weight of milking and able to lay eggs and as a result of the correlation analysis, while the broodstock weight and egg diameter and weight increased, absolute and relative egg yield values decreased. While egg weight and egg diameter were increasing, absolute and relative egg productivity decreased. Many studies reported that many biological and environmental factors that affect the egg yield and size of the rainbow trout, the main of which is the size, genotype and feeding regime of the fish (Bromage \& Roberts, 1995). In other studies, evaluating the relationship between broodstock weight and egg yield reported that the diameter of the eggs changes depending on the broodstock weight (Beacham \& Murray, 1987; Kazakov, 1981; Baki, Çakmak, Baki \& Altuntaş, 2015) and there is a positive relationship between rootstock weight and egg productivity (Çakmak, Aksungur, Firidin, Çavdar \& 
Kurtoğlu, 2005; Serezli, Güzel \& Kocabaşi 2010). In addition to these studies, it was reported that egg size has an effect on egg productivity (Fleming \& Gross, 1990; Cunnington \& Brooks, 2000; Bozkurt \& Seçer, 2006), while it affects absolute egg yield positively with broodstock weight and negatively affects relative egg yield (Çakmak et al. 2005, Serezli et al. 2010; Erbaş \& Başçınar, 2013; Baki et al. 2015).

Although the nutritional value and biochemical properties of fish fillet are quite well known (Usydus, Szlinder-Richert, Adamczyk \& Szatkowska, 2011; Kaliniak, Florek \& Skalecki, 2015; ElShehawy, Gab-Alla \&Mutwally, 2016; Mehta \& Nayaka, 2017), biochemical properties of fish eggs are not fully understood yet, with respect to both their biological and physicochemical aspects. In the way of biochemical characteristics, the composition of fish eggs differs from that of fish fillet (ElShehawy et al. 2016) or chicken and quail eggs (Oroian, Cighi, Orioan \& Gavrila, 2013; Vakili \& Majidzadeh Heravi, 2016). The biochemical composition of eggs of the broodstock are to some extent affected by the protein and energy content in feed (Abdel-Fattah \& Mamdouh, 2008; Kowalska-Goralska et al. 2019) as well as by many other factors (such as fish species, age and environmental conditions reported by Bekhit, Morton, Dawson, Zhao and Lee, 2009 and Yanes-Roca, Rhody, Nystrom and Main, 2009). However, there are quite considerable between-species differences, particularly with respect to the crude protein content. For example, in different trout and salmon species the crude protein value was also observed between $17.69 \pm 0.18$ $26.8 \pm 1.8 \%$ (Oncorhynchus tshawytscha: Bekhit et al. 2009, Kowalska-Goralska et al. 2019; Salmo trutta: Kowalska-Goralska et al. 2019; Salmo trutta labrax: Mol \& Turan, 2008; Oncorhynchus mykiss: Machado et al. 2016; İnanlı, Çoban, Yılmaz, Özpolat, \& Kuzgun, 2019; Kaya Öztürk, Baki, Öztürk, Karayücel, \& Uzun Gören, 2019). The crude protein values of rainbow trout eggs in the current study were similar to the egg crude protein values of trout species in previous studies. Katsiadaki, Taylor and Smith (1999) emphatic the importance of dry matter content to the quality grade of cod eggs and demonstrated the increased in roe quality with the increase in the dry matter content. The present study may support this contention, since the nutritional value (represented by the contents of crude protein and lipid) is directly proportional related to the dry matter in rainbow trout eggs. The lipid content of fish eggs is effective both in the nutritional quality of human consumption and in the production of fish, from the fertilization rates of the eggs to the quality of the harvested fish. (Kaitaranta \& Ackman 1981). In the present study, crude lipid content of trout eggs at all stations (3.19 $\pm 0.18-5.76 \pm 0.14 \%)$ was lower than other studies with eggs of trout species (Mol \& Turan, 2008; Bekhit et al. 2009; Machado et al. 2016; Inanlı et al. 2019). These differences in findings are thought to be due to fish species, broodstock from which eggs are obtained, and the quality of feed of broodstocks.

Table 5. Amino acid composition of eggs of rainbow trout in belonging to different stations

\begin{tabular}{|c|c|c|c|c|c|}
\hline Amino Acids & I.Station & II.Station & III.Station & IV.Station & V.Station \\
\hline Ala $(g / 100 g)$ & $2.80 \pm 0.04^{b}$ & $2.26 \pm 0.01^{\mathrm{a}}$ & $2.51 \pm 0.05^{a}$ & $2.48 \pm 0.01^{a}$ & $3.27 \pm 0.02^{c}$ \\
\hline $\operatorname{Arg}(g / 100 g)$ & $2.17 \pm 0.02^{c}$ & $1.72 \pm 0.02^{a}$ & $2.02 \pm 0.01^{b}$ & $1.85 \pm 0.01^{a}$ & $2.54 \pm 0.02^{d}$ \\
\hline Asp $(g / 100 g)$ & $3.12 \pm 0.02^{\mathrm{cd}}$ & $2.37 \pm 0.05^{a}$ & $2.75 \pm 0.01^{b c}$ & $2.67 \pm 0.02^{\mathrm{ab}}$ & $3.47 \pm 0.09^{d}$ \\
\hline Cys (g/100g) & $0.51 \pm 0.01^{\mathrm{a}}$ & $0.53 \pm 0.01^{a}$ & $0.51 \pm 0.01^{a}$ & $0.53 \pm 0.01^{a}$ & $0.71 \pm 0.01^{b}$ \\
\hline Glu $(g / 100 g)$ & $3.91 \pm 0.01^{c}$ & $3.05 \pm 0.02^{\mathrm{a}}$ & $3.63 \pm 0.10^{b c}$ & $3.37 \pm 0.06^{\mathrm{ab}}$ & $4.54 \pm 0.07^{d}$ \\
\hline Gly $(\mathrm{g} / 100 \mathrm{~g})$ & $1.03 \pm 0.01^{a}$ & $0.92 \pm 0.05^{a}$ & $1.07 \pm 0.02^{\mathrm{ab}}$ & $0.92 \pm 0.01^{a}$ & $1.29 \pm 0.04^{b}$ \\
\hline His $(g / 100 g)$ & $1.30 \pm 0.01^{\mathrm{c}}$ & $0.99 \pm 0.02^{\mathrm{a}}$ & $1.20 \pm 0.02^{b c}$ & $1.09 \pm 0.02^{\mathrm{ab}}$ & $1.55 \pm 0.04^{d}$ \\
\hline Ile $(g / 100 g)$ & $1.76 \pm 0.05^{\mathrm{ab}}$ & $1.29 \pm 0.02^{\mathrm{a}}$ & $1.47 \pm 0.03^{a}$ & $1.45 \pm 0.10^{\mathrm{a}}$ & $2.01 \pm 0.07^{b}$ \\
\hline $\operatorname{Leu}(\mathrm{g} / 100 \mathrm{~g})$ & $3.13 \pm 0.07^{b}$ & $2.56 \pm 0.03^{a}$ & $2.92 \pm 0.01^{b}$ & $2.96 \pm 0.05^{b}$ & $3.99 \pm 0.01^{c}$ \\
\hline Lys (g/100g) & $3.51 \pm 0.02^{c}$ & $2.87 \pm 0.02^{\mathrm{a}}$ & $3.22 \pm 0.02^{\mathrm{b}}$ & $3.04 \pm 0.02^{a b}$ & $4.40 \pm 0.04^{d}$ \\
\hline $\operatorname{Met}(g / 100 g)$ & $1.08 \pm 0.02^{c}$ & $0.85 \pm 0.01^{a}$ & $1.03 \pm 0.01^{b c}$ & $0.91 \pm 0.01^{\mathrm{ab}}$ & $1.30 \pm 0.03^{d}$ \\
\hline Orn $(g / 100 g)$ & $0.13 \pm 0.01^{a}$ & $0.12 \pm 0.01^{\mathrm{a}}$ & $0.14 \pm 0.01^{a}$ & $0.13 \pm 0.01^{a}$ & $0.14 \pm 0.01^{a}$ \\
\hline Phe (g/100g) & $1.92 \pm 0.02^{b}$ & $1.47 \pm 0.01^{\mathrm{a}}$ & $1.74 \pm 0.03^{a b}$ & $1.64 \pm 0.03^{a b}$ & $2.25 \pm 0.06^{c}$ \\
\hline $\operatorname{Pro}(\mathrm{g} / 100 \mathrm{~g})$ & $1.84 \pm 0.02^{b}$ & $1.62 \pm 0.02^{\mathrm{a}}$ & $1.86 \pm 0.02^{b}$ & $1.73 \pm 0.02^{\mathrm{ab}}$ & $2.23 \pm 0.01^{c}$ \\
\hline $\operatorname{Ser}(g / 100 g)$ & $1.98 \pm 0.02^{b}$ & $1.80 \pm 0.01^{\mathrm{a}}$ & $2.01 \pm 0.02^{b}$ & $1.95 \pm 0.03^{a b}$ & $2.46 \pm 0.01^{c}$ \\
\hline The $(g / 100 g)$ & $1.82 \pm 0.03^{a b}$ & $1.52 \pm 0.08^{a}$ & $1.75 \pm 0.03^{a}$ & $1.66 \pm 0.01^{\mathrm{a}}$ & $2.11 \pm 0.04^{b}$ \\
\hline $\operatorname{Tyr}(g / 100 g)$ & $1.36 \pm 0.01^{b}$ & $1.06 \pm 0.05^{a}$ & $1.19 \pm 0.01^{\mathrm{ab}}$ & $1.15 \pm 0.02^{\mathrm{a}}$ & $1.67 \pm 0.01^{c}$ \\
\hline $\mathrm{Val}(\mathrm{g} / 100 \mathrm{~g})$ & $2.45 \pm 0.01^{c}$ & $1.78 \pm 0.08^{a}$ & $2.10 \pm 0.02^{b}$ & $2.05 \pm 0.02^{b}$ & $2.87 \pm 0.02^{d}$ \\
\hline $\operatorname{Tau}(g / 100 g)$ & $0.13 \pm 0.01^{a}$ & $0.13 \pm 0.01^{a}$ & $0.13 \pm 0.01^{a}$ & $0.14 \pm 0.01^{a}$ & $0.14 \pm 0.01^{a}$ \\
\hline$\Sigma A A(g / 100 g)$ & $35.94 \pm 0.02^{c}$ & $28.90 \pm 0.31^{a}$ & $33.26 \pm 0.05^{b}$ & $31.72 \pm 0.01^{b}$ & $42.96 \pm 0.06^{\circ}$ \\
\hline$\Sigma E A A(g / 100 g)$ & $19.15 \pm 0.01^{c}$ & $15.04 \pm 0.17^{a}$ & $17.46 \pm 0.02^{\mathrm{b}}$ & $16.66 \pm 0.10^{b}$ & $23.03 \pm 0.04^{c}$ \\
\hline$\Sigma N E A A(g / 100 g)$ & $16.80 \pm 0.14^{d}$ & $13.86 \pm 0.22^{a}$ & $15.79 \pm 0.07^{c}$ & $15.06 \pm 0.09^{b}$ & $19.93 \pm 0.02^{e}$ \\
\hline$B C A A(g / 100 g)$ & $7.35 \pm 0.15^{c}$ & $5.62 \pm 0.12^{\mathrm{a}}$ & $6.50 \pm 0.08^{b}$ & $6.47 \pm 0.17^{b}$ & $8.88 \pm 0.08^{d}$ \\
\hline$S A A(g / 100 g)$ & $1.59 \pm 0.01^{c}$ & $1.37 \pm 0.02^{\mathrm{a}}$ & $1.54 \pm 0.03^{c}$ & $1.45 \pm 0.03^{b}$ & $2.01 \pm 0.04^{d}$ \\
\hline $\operatorname{ArAA}(g / 100 g)$ & $3.28 \pm 0.04^{d}$ & $2.53 \pm 0.07^{a}$ & $2.94 \pm 0.04^{c}$ & $2.80 \pm 0.08^{b}$ & $3.92 \pm 0.10^{\mathrm{e}}$ \\
\hline$B A A(g / 100 g)$ & $6.98 \pm 0.08^{d}$ & $5.58 \pm 0.03^{a}$ & $6.44 \pm 0.01^{c}$ & $5.98 \pm 0.01^{b}$ & $8.50 \pm 0.02^{\mathrm{e}}$ \\
\hline$A A A(g / 100 g)$ & $7.02 \pm 0.03^{d}$ & $5.42 \pm 0.04^{a}$ & $6.39 \pm 0.14^{c}$ & $6.03 \pm 0.11^{b}$ & $8.02 \pm 0.03^{e}$ \\
\hline$E A A / N E A A$ & $1.23 \pm 0.01^{b c}$ & $1.19 \pm 0.01^{a}$ & $1.20 \pm 0.01^{\mathrm{ab}}$ & $1.20 \pm 0.02^{\mathrm{ab}}$ & $1.25 \pm 0.01^{c}$ \\
\hline$E A A I$ & $1.28 \pm 0.01^{b c}$ & $1.18 \pm 0.01^{\mathrm{a}}$ & $1.24 \pm 0.01^{b}$ & $1.22 \pm 0.01^{\mathrm{ab}}$ & $1.36 \pm 0.01^{c}$ \\
\hline
\end{tabular}

Values in same rows marked with different letters are significantly different $(\mathrm{P}<0.05)$. 
The chemical composition of fish eggs is often examined to evaluate their quality, as the eggs must satisfy the nutritional needs for embryonic and larval development (Furuita et al. 2002). In particular, the study of lipids and fatty acids has been used in the assessment of egg quality because their composition can influence the fertilization rate, hatching, survival and growth of fish larvae (Tocher, 2010). PUFAs such as $\mathrm{C} 22: 6 n-3, C 20: 5 n-3$ and $C 20: 4 n-6$ have been shown to be essential for both reproductive control and larval development in many fish species (Izquierdo, Fernandez-Palacios, Tacon, 2001). In addition to them, the fish eggs providing significant amounts of long chain Ф-3 PUFA, mainly 20:5n-3 and 22:6n-3 (Lu, Ma, Williams \&Chung, 1979), reported that exert beneficial role in the prevention of diseases (Lee, O'Keefe, Lavie, Marchioli \& Harris, 2008). In the fatty acid composition of rainbow trout eggs a high content of total PUFAs (between 41.63 and $46.37 \%$ of the total amount of fatty acids) were with the $\omega-3 \quad(21.21-24.63 \%)$ and $\omega-6 \quad(13.11-17.48 \%)$ contents. It is established that the $\omega-3 / \omega-6$ ratios in eggs of rainbow trout were changed between $1.21 \pm 0.02$ and $1.88 \pm 0.01$ and the statistical difference among stations is important $(P<0.05)$. And the higher percentage of total $\omega-3$ 's in rainbow trout eggs were mainly due to higher sum of C20:5n-3, DHA and EPA. Most of the polyunsaturated fatty acids in fish eggs consist of DHA and EPA and with an approximate DHA/EPA ratio of 2:1 or more and without detectable differences between marine and fresh water species (Kairanta \& Linko 1984; Haliloğlu, Aras, Yanık, Atamanalp \& Kocaman, 2003; Bekhit et al. 2009; Kowalski-Goralska et al. 2019). In this study, the eggs obtained from all stations had DHA/EPA ratios between $2.81 \pm 0.22-3.85 \pm 0.09$ and higher than the data in this literature. In the current study, the EPA+DHA value in rainbow trout eggs obtained from all stations varied between $20.25 \pm 0.28$ and $21.28 \pm 0.04$ $(P<0.05)$. This value was lower than previous studies with the eggs of salmonid species (Ballestrazzi, Rainis \& Maxia, 2003; Haliloğlu et al. 2003; Mol \& Turan, 2008; Bekhit et al. 2009; Kalogeropoulos, Mikellidi, Nomikos \& Chiou, 2012; Harring, Jonston, Wigand, Fisk, \& Pitcher, 2016; Kowalska-Groralska et al. 2019; Murzina et al. 2019). Among many other fish species eggs were determined the highest EPA+DHA level was in the European hake eggs (Merluccius merluccius) (44.4\%), and the lowest in the catla eggs (Catla catla) (8.9\%) (Kaliniak et al. 2015). In many studies emphasized that besides the wild or culture of the broodstocks, nutrition and physicochemical conditions are effective on egg EPA+DHA values (Salze, Tocher, Roy, \& Robertson, 2005; Yeşilayer \& Türk, 2018, Thorn, Dick, Oviedo, Guglielmo, \& Morbey, 2018). However, in this study, it is not correct to say what is effective on EPA+DHA values since it is only aimed to determine the fatty acid composition of the eggs. The atherogenic, thrombogenic and hypercholesterolemic potential of commercial rainbow trout eggs were evaluated by calculating the respective fat quality indices ( $\mathrm{Al}, \mathrm{TI}$ and $\mathrm{HH}$ ) and the results are presented in Table 4. Different studies reported that values of IA and IT, the fatty acid quality parameters, should not be more than 1.00 for human health (ChávezMendoza et al. 2014; Łuczynska, Paszczyk, Nowosad \& Łuczynski, 2017; Kowalska-Goralska et al. 2019) and high $\mathrm{H} / \mathrm{H}$ ratio in diets is considered to be more beneficial for human health (Fernandes et al. 2014). It is clear that in this study, rainbow trout eggs IA and IT values were lower than 1.00 and $\mathrm{H} / \mathrm{H}$ ratios were high and these values were sufficient for human health according to the literature.

To sum up fatty acid composition, it should be noted that the eggs of the rainbow trout eggs examined are rich in PUFA, including EPA and DHA, their contents approximating or exceeding those in the meat or liver fat of many marine fish (Usydus et al. 2011; Kaliniak et al. 2015; El Shehawy et al. 2016; Mehta \& Nayaka, 2017), which is very advantageous from the standpoint of dietary recommendations and medical disease prevention (Swanson, Block \& Mousa, 2012; Simopoulos, 2016).

Edible fish eggs are considered as highly nutritive foods, having well balanced proteins with essential amino acids (Iwasaki \& Harada, 1985; De la Cruz-García, López-Hernández, González-Castro, Rodríguez-Bernaldo De Quirós, \& Simal-Lozano, 2000). The amino acid composition of fish eggs differs from that of fish meat (Mehta \& Nayaka, 2017; Usydus et al. 2009) and of mammalian milk (Rafiq et al. 2016) or poultry eggs (Nutrient Composition Tables, 2017). The detailed amino acid composition of rainbow trout eggs is given in Table 5. The most abundant amino acid in all of them was glutamic acid (3.95 $\pm 0.02-4.54 \pm 0.07 \mathrm{~g} / 100 \mathrm{~g})$, followed by leucine, lysine, aspartic acid, alanine and valine in that order. Studies have reported that the most common amino acids in the eggs of some fish species are glutamic acid and leucine (Riverio et al. 2003; Bulut, 2004; Kaya Öztürk et al. 2019). Compared to studies with different trout species, it was determined that the tyrosine value was similar and higher than other amino acids types (Seagrean, Morey, \& Dassow, 1954; Suyama, 1958; Cowey, Daisley, \& Parry, 1972; Satia, Donaldson, Smith, \& Nightigal, 1974). Gunasekera, Shim and Lam (1996) reported that the highest contents of histidine among EAAs, and proline among NAAs in the Nile tilapia eggs, while the $\Sigma A A$ content increased with the dietary protein level. Lochmann, Goodwin, Lochmann, Stone and Clemment (2007) reported that the golden shiners eggs (Notemigonus crysoleucas) showed the highest amounts of glutamic acid and leucine and the lowest contents of tryptophan. The total amino acid content ranged from $28.40 \pm 0.31$ to $42.96 \pm 0.06 \mathrm{~g} / 100 \mathrm{~g}$. As a result of the correlation analysis, it was found that the egg diameter and weight had a negative effect on the total amino acid values of the eggs $(r=-0.73)$. The EAA content of all samples was higher than NEAA content; the ratio of EAA/NEAA ranged from $1.19 \pm 0.01$ to $1.25 \pm 0.01$. When evaluated in terms of amino acid quality, the BCAA, SAA, ArAA, BAA and AAA accounted 
for $19.45-20.67 \%, \quad 4.68-4.74 \%, \quad 8.75-9.12 \%, \quad 19.30$ $19.78 \%$ and $18.75-18.66 \%$, respectively, of the total amino acid content of the rainbow trout eggs. Certainly, many other quality parameters of amino acids should be considered from the point of view of human nutritional needs (Reeds, 2000; Adeyeye, 2010). The main criterion for the assessment of protein value is the content of essential amino acids, including sulfuric amino acids (Kowalska-Groralska et al. 2019). When the amino acid data of this study are evaluated, the concentration of total essential amino acids in rainbow trout eggs was determined higher than reference $\mathrm{FAO} / \mathrm{WHO}$ pattern (Gong et al. 2013).

\section{Conclusion}

In the study, it was aimed to determine the rootstock productivity and egg quality values and to reveal the relationship between productivity and quality in enterprise producing trout eggs and fry at different stations. According to the results of productivity analysis, broodstock weight was determined to be significantly effective on egg diameter and weight, absolute and relative. The biochemical, amino asit and fatty acid compositions of rainbow trout eggs were investigated for their possible relation to egg 'quality', which may be revealed from in the fertilization success of eggs to harvesting fish. Commercial egg products can be considered as food of high quality, providing significant amounts of protein, fat, amino acid and fatty acids. Differences were observed between the fatty acid profiles of rainbow trout eggs in all stations. The rainbow trout eggs were studied contain significant amounts of long chain omega-3 PUFA and were beneficial fatty acid profiles, with very low thrombogenic and atherogenic potential. As a result of the study, the amino acid and fatty acid values of rainbow trout eggs were determined to be sufficient for embryonic and larval development of fish and this values showed rainbow trout eggs potential source of food for human consumption.

\section{Ethical Statement}

Broodstock and egg samples used in the study were randomly sampled by the business employees. For this reason, this manuscript does not need ethical approval.

\section{Funding Information}

This work was supported by Sinop University Scientific Research Coordination Unit. Project Number: SÜF-1901- 18-45, 2018.

\section{Author Contributions}

BB: Conceptualization, Supervision, Project Administration; DKÖ: Investigation, Writing - Review \&Editing, Visualization; ST: Methodology, Resources

\section{Conflict of Interest}

The author(s) declare that they have no known competing financial or non-financial, professional, or personal conflicts that could have appeared to influence the work reported in this paper

\section{Acknowledgements}

This work was supported by Sinop University Scientific Research Coordination Unit. Project Number: SÜF-1901- 18-45, 2018. A part of this study was presented as a oral and poster presentation with Turkish abstract only in "National Fisheries and Aquaculture Symposium", 24-26 September 2019, Mersin, Turkey.

\section{References}

Abdel-Fattah, M.E.S., \& Mamdouh, K. (2008). Effects of dietary protein and energy levels on spawning performance of Nile tilapia (Oreochromis niloticus) broodstock in a recycling system. Aquaculture, 280, 179-184.

Adeyeye, E.I. (2010). Effect of cooking and roasting on the amino acid composition of raw groundnut (Arachis hypogaea) seeds. Acta Scientiarum Polonorum Technologia Alimentaria, 9, 201-216.

AOAC Association of Official Analytical Chemists (1995). Official methods of analysis 16th Ed. Washington DC, USA,

Aras, M.S. (1988). Balık üretimi esasları ve genel bilgiler. Atatürk Üniversitesi Ziraat Fakültesi Zootekni Bölümü, Erzurum, 12. (in Turkish).

Baki, H., Çakmak, E., Baki, B., \& Altuntaş, C. (2015). III.Nesil (F3) Karadeniz alabalığı (Salmo trutta labrax Pallas, 1814) anaç ağırlığı ve kuluçka ilişkisi. Türk Tarım-Gıda Bilim ve Teknolojisi Dergisi, 3(7), 550-555. (in Turkish).

Ballestrazzi, R., Rainis, S., \& Maxia, M. (2003). The effect of dietary coconut oil on reproductive traits and egg fatty acid composition in rainbow trout (Oncorhynchus mykiss), Aquaculture International, 11, 289-299.

Beacham, T.D., \& Murray, C.B., (1987). Adaptive variation in body size, age, morphology, egg size and developmental biology of chum salmon (Oncorhyncus keta) in British Colombia. Canadian Journal of Fisheries and Aquatic Sciences. 44, 244-261.

Bekhit, A., Morton, J.D., Dawson, C.O., Zhao, J.H., \& Lee, H. (2009). Impact of maturity on the physicochemical and biochemical properties of Chinook salmon roe. Food Chemistry, 117, 318-325.

Bell, J.G., \& Sargent, J.R. (2003). Arachidonic acid in aquaculture feeds: current status and future opportunities. Aquaculture, 218, 491-499.

Bromage, N., \& Roberts, R.J. (1995). Broodstock management and larval quality. Blackwell Scieces Ltd. Osney Mead. Oxford WCIn OEL.

Boulekbache, H. (1981). Energy metabolism in fish development. American Zoologist, 12, 377-389.

Bozkurt, Y., \& Seçer, S. (2006). Relationship between spermatozoa motility, egg size, fecundity and fertilization success in brown trout (Salmo trutta fario). Journal of Biological Sciences, 9, 2141-2144.

Bulut, M. (2004). Levrek (Dicentrarchus labrax L., 1758) ve çipura (Sparus aurata L., 1758) yumurtalarının 
biyokimyasal kompozisyonu. Ege Journal of Fisheries and Aquatic Sciences, 21(1-2), 129-132. (in Turkish)

Cejas, J.R., Almansa, E., Jerez, S., Bolanos, A., Felipe, B., \& Lorenzo, A. (2004). Changes in lipid class and fatty acid composition during development in white seabream (Diplodus sargus) eggs and larvae. Comparative Biochemistry and Physiology - Part B, 139, 209-216.

Chavez-Mendoza, C., Garcia-Macias, J.A., Delia, A., AlarconRojo, A.D., Ortega-Gutierrez, J.A., Holguin-Licon, C., \& Corral-Flore, G. (2014). Comparison of fatty acid content of fresh and frozen fillets of rainbow trout (Oncorhynchus mykiss) Walbaum. Brazilian Archives of Biology and Technology, 57(1), 103-109.

Cowey, C.B., Daisley, K.W., \& Parry, G. (1972). Study of amino acids, free or as components of protein and of some $B$ vitamins in the tissues of Atlantic salmon, Salmo salar, during migration. Comparative Biochemistry and Physiology, 7, 29-38.

Cunnington, D.C., \& Brooks, R.J. (2000). Optimal egg size theory: Does predation by fish affect egg size in Ambystoma maculatum. Journal Herpetology, 34(1), 4653.

Çakmak, E., Aksungur, N., Firidin, Ş., Çavdar, Y. \&, Kurtoğlu, i.Z. (2005). Doğal ve kuluçkahane kökenli Karadeniz Alabalığı (Salmo trutta labrax, Pallas 1811) anaçlarında üreme özelliklerinin irdelenmesi. Ulusal Su Günleri, 28-30 Eylül 2005, Trabzon. (in Turkish).

Çelikkale, M.S. (1998). İ̧̧ su balıkları ve yetiştiriciliği. Cilt I, Karadeniz Teknik Üniversitesi Basımevi, Trabzon. 419. (in Turkish).

De la Cruz-García, C., López-Hernández, J., González-Castro, M. J., Rodríguez-Bernaldo De Quirós, A. I., \& Simal-Lozano, J. (2000). Protein, amino acid and fatty acid contents in raw and canned sea urchin (Paracentrotus lividus) harvested in Galicia (NW Spain). Journal of the Science of Food and Agriculture, 80, 1189-1192.

ElShehawy, S.M., Gab-Alla A.A., \& Mutwally H.M.A. (2016). Amino acids pattern and fatty acids composition of the most important fish species of Saudi Arabia. International Journal of Food Science and Nutrition Engineering, 6, 32-41.

Erbaş, H.í., Baş̧̧ınar, N. (2013). Yemleme sıklığının Karadeniz alabalığı (Salmo trutta labrax Pallas, 1811)'nın sperm ve yumurta kalitesine etkisinin belirlenmesi. Biyoloji Bilimleri Araştırma Dergisi, 6(1), 11-16. (in Turkish).

Fernandes, C.E., Vasconcelos, M.A.S., Ribeiro, M.A., Sarubbo, L.A., Andrade, S.A.C., \& Filho, A.B.M. (2014). Nutritional and lipid profiles in marine fish species from Brazil. Food Chemistry, 160, 67-71. https://doi.org/10.1016/j.foodc hem.2014.03.055

Fleming, I.A., \& Gross, M.R. (1990). Latitudinal clines: A tradeoff between egg number and size in pasific salmon. Ecology. 71, 1-11.

Furuita, H., Tanaka, H., Yamamoto, T., Suzuki, N., Takeuchi, T. (2002). Effects of high levels of n-3 HUFA in broodstock diet on egg quality and egg fatty acid composition of Japanese flounder Paralichthys olivaceus. Aquaculture, 210, 323-333.

Furuita, H., Ohta, H., Unuma, T., Tanaka, H., Kagawa, H., Suzuki, N., \& Yamamoto, T. (2003). Biochemical composition of eggs in relation to egg quality in the Japanese eel, Anguilla japonica. Fish Physiology and Biochemistry, 29, 37-46.

Gimenez, G., Estevez, A., Lahnsteiner, F., Zecevic, B., Bell, J.G., Henderson, R.J., Pinera, J.A., \& Sanchez-Prado, J.A.
(2006). Egg quality criteria in common dentex (Dentex dentex). Aquaculture, 260, 232-243.

Gong, Y., Huang, Y., Gao, L., Lu, J., Hu, Y., Xia, L., \& Huang, H. (2013). Nutritional composition of caviar from three commercially farmed sturgeon species in China. Journal of Food and Nutrition Research, 1(5), 108-112.

Gunasekera, R.M., Shim, K.F., \& Lam, T.J. (1996). Effect of dietary protein level on spawning performance and amino acid composition of eggs of Nile tilapia, Oreochromis niloticus. Aquaculture, 146 (1-2), 121-134.

Haliloğlu, H.i., Aras, N.M., Yanık, T., Atamanalp, M. \& Kocaman, E.M., (2003). Investigation of changes in fatty acid composition at early development stages of rainbow trout (Oncorhynchus mykiss). Turkish Journal of Veterinary and Animal Sciences. 27, 1105-1109.

Hardy, R.W., \& Fornshell, G.C.G. (2000). Rainbow trout culture. Brannon EL. In: R. Stickney (ed.) Fish Culture, 716-722 p. John Wiley \& Sons, New York, USA.

Harring, M.W., Jonston, T.A., Wigand, M.D., Fisk, A.T., \& Pitcher, T.E. (2016). Differences in egg quantity and quality among hatchery- and wild-origin Chinook salmon (Oncorhynchus tshawytscha). Canadian Journal of Fisheries and Aquatic Science, 73, 1-10 hptt:doi.org/10.1139/cjfas-2015-0083

IBM Corp. Released 2012. IBM SPSS Statistics for Windows, Version 21.0. Armonk, NY: IBM Corp.

İnanlı, A.G., Çoban, Ö.E., Yılmaz, Ö., Özpolat, E. \& Kuzgun, N.K. (2019). Assessment of vitamin compositions and cholesterol levels of carp (Cyprinus carpio carpio) and rainbow trout (Oncorhynchus mykiss) caviars. Ege Journal of Fisheries and Aquatic Sciences, 36(3), 293299.

Iwasaki, M., \& Harada, R. (1985). Proximate and amino acid composition of the roe and muscle of selected marine species. Journal of Food Science, 50, 1585-1587.

Izquierdo, M.S., Fernandez-Palacios, H., \& Tacon, A.G.J., (2001). Effect of broodstock nutrition on reproductive performance of fish. Aquaculture, 197, 25-42.

Kaitaranta, J.K., \& Ackman, R.G. (1981). Total lipids and lipid classes of fish roe. Comparative Biochemistry and Physiology Part-B, 69, 725-729.

Kairanta, J.K. \& Linko, R.R. (1984). Fatty acids in the roe lipids of common food fishes. Comparative Biochemistry and Physiology Part-B, 79, 331-334.

Kaliniak A., Florek M., \& Skałecki P. (2015). Profile of fatty acids in meat, roe, and liver of fish. ZYWNOSC-Nauka Technologia Jakosc, 99, 29-40.

Kalogeropoulos, N. Mikellidi, A., Nomikos, T., \& Chiou, A. (2012). Screening of macro- and bioactive microconstituents of commercial finfish and sea urchin eggs. LWT - Food Science and Technology, 46, 525-531.

Katsiadaki, I.G., Taylor, K.D.A., \& Smith, G. (1999). Assessment of quality of cod roes and relationship between quality and maturity stage. Journal of the Science of Food and Agriculture, 79, 1249-1259.

Kaya Öztürk, D., Baki, B., Öztürk, R., Karayücel, S., \& Uzun Gören, G. (2019). Determination of growth performance, meat quality and colour attributes of large rainbow trout (Oncorhynchus mykiss) in the southern Black Sea coasts of Turkey. Aquaculture Research, 50, 3763-3775. https://doi.org/10.1111/are.14339

Kazakov, R.V. (1881). The effect of the size of Atlantic Salmon, Salmo salar L., eggs on embryos and alevins. Journal of Biology, 19, 353-360. 
Kjorsvik, E., Mangor Jensen, A., \& Holmefjord, I. (1990). Egg quality in fishes. Advances in Marine Biology, 26, 71113.

Kowalska-Góralska, M., Formicki, K., Dobrzański, Z. Wondołowska-Grabowska, A., Skrzyńska, E., KorzeleckaOrkisz, A., Nędzarek, A., \& Tański, A. (2019). Nutritional composition of Salmonidae and Acipenseridae fish eggs. Annals of Animal Science, https://doi.org/10.2478/aoas2019-0072

Lee, J.H., O'Keefe, J.H., Lavie, C.J., Marchioli, R., \& Harris, W.S. (2008). Omega-3 fatty acids for cardio protection. Mayo Clinic Proceedings, 83, 324-332.

Leitritz, Z., \&Lewis, R.C. (1980). Trout and salmon culture. California Fishery Bulletin, 164-197.

Lu, J.Y., Ma, Y.M., Williams, C., \& Chung, R.A. (1979). Fatty and amino acid composition of salted mullet roe. Journal of Food Science, 44, 676-677.

Łuczynska, J., Paszczyk, B., Nowosad, J., \& Łuczynski, M.J. (2017). Mercury, fatty acids content and lipid quality indexes in muscles of freshwater and marine fish on the polish market. Risk assessment of fish consumption. International Journal of Environmental Research and Public Health, https://doi.org/10.3390/ijerph14101120

Lochmann, S.E., Goodwin, K.J., Lochmann, R.T., Stone N.M., \& Clemment T. (2007). Volume and lipid, fatty acid, and amino acid composition of golden shiner eggs during a spawning season. North American Journal of Aquaculture, 69, 116-126.

Machado, T.M., Tabata, Y.A., Takahashi, N.S., Casarini, L.M., Pinheiro Neiva, C.R., Henriques, M.B. (2016). Caviar substitute produced from roes of rainbow trout (Oncorhynchus mykiss). Acta Scientiarum Technology, 38(2), 233-240.

Maeland, A., Ronnestad, I., \& Waagbo, R. (2003). Short communication-folate in eggs and developing larvae of Atlantic halibut, Hippoglossus hippoglossus L. Aquaculture Nutrition, 9, 185-188.

Mehta, N.K., \& Nayaka, B.B. (2017). Bio-chemical composition, functional, and rheological properties of fresh meat from fish, squid, and shrimp: A comparative study. International Journal of Food Properties, 20, 707-721.

Mol, S., \& Turan, S. (2008) Comparison of proximate, fatty acid and amino acid compositions of various types of fish roes. International Journal of Food Properties, 11(3), 669-677. https://doi.org/10.1080/10942910701611170

Mourente, G., \&Vazquez, R., (1996). Changes in the content of total lipid, lipid classes and their fatty acids of developing eggs and unfed larvae of the Senegal sole, Solea senegalensis Kaup. Fish Physiology and Biochemistry, 15, 221-235.

Murzina, S.A., Nefedova, Z.A., Pekkoeva, S.N., Veselov, A.E., Efremov, D.A., Ruokolainen, T.R., \& Nemova, N.N. (2019). Dynamics of lipid and fatty acid content at early ontogenesis stages in Pink Salmon Oncorhynchus gorbuscha (Walbaum, 1792) in a natural environment (Indera River, Kola Peninsula). Russian Journal of Developmental Biology, 50(4), 180-188.

Nutrient Composition Tables. (2017). Assayd egg nutrients. American egg board, Chicago, USA (https://www.aeb.org/food-manufacturers/eggsproduct-overview/nutrient-composition-tables access date: 12.06 .2020$)$

Oroian, T.E., Cighi, V., Oroian, R.G., \& Gavrila V. (2013). Chemical composition of spawns and carp milt in
Cyprinus carpio populations from Arinis fishery complex Maramures area. AACL Bioflux, 6, 614-617.

Planas, M., Labranta, U., Fernandez-Reiriz, M.J., Ferreiro, M.J., Munilla, R., \& Garrido, J.L. (1993). Chemical changes during early development inturbot (Scophthalmus maximus) eggs and larvae. In: Walter, B.T., Fyhn, H.J. (Eds.), Physiological and Biochemical Aspects of Fish Development. University of Bergen, Norway, 269-278

Rafiq, S., Huma, N., Pasha, I., Sameen, A., Mukhtar, O., \& Khan, M.I. (2016). Chemical composition, nitrogen fractions and amino acids profile of milk from different animal species. Asian-Australasian Journal of Animal Sciences, 29, 1022-1028.

Reeds, P.J. (2000). Dispensable and indispensable amino acids for humans. The Journal of Nutrition, 130(7), 1835-1840.

Riverio, I., Guisande, C., Franco, C., De Lanzos, A.L., Maneiro, I., \& Veraga, A.R. (2003). Egg and larval amino acid composition as indicators of niche resource partitioning in pelagic fish species. Marine Ecology Progress Series, 260, 255-262.

Ronnestad, I., \& Fyhn, H.J. (1993). Metabolic aspects of free amino acids in developing marine fish eggs and larvae. Reviews in Fisheries Science, 1, 239-259.

Ronnestad, I., Lie, O., \& Waagbo, R. (1997). Vitamin B6 in Atlantic halibut, Hippoglossus hippoglossus-endogenous utilization and retentionin larvae fed natura zooplankton. Aquaculture, 157, 337-345.

Salze, G., Tocher, D.R., Roy, W.J., \& Robertson, D.A. (2005). Egg quality determinants in cod (Gadus morhua L.): egg performance and lipids in eggs from farmed and wild broodstock. Aquaculture Research, 36, 1488-1499.

Sargent, J.R., Henderson, R.J., \& Tocher, D.R., (1989). The lipids. In: Halver, J.E. (Ed.), Fish Nutrition. Academic Press, New York, pp. 153-218.

Sargent, J.R., (1995). Origins and functions of egg lipids: nutritional implications. In: Bromage, N., Roberts, R.J. (Eds.), Broodstock Management and Egg and Larva Quality. Blackwell Science, Cambridge, UK, 353-372.

Satia, B.P., Donaldson, L.R., Smith, L.S., \& Nightigal, J.N. (1974). Composition of ovarian fluid and eggs of the University of Washington strain of rainbow trout (Salmo gairdneri) fingerlings. Journal of the Fisheries Research Board of Canada, 31, 1796-1799.

Seagrean, H.L, Morey, D.E., \& Dassow, J.A. (1954). The amino acid content of roe at different stages of maturity from five species of Pacific salmon. The Journal of Nutrition, $53,139-149$

Serezli, R., Güzel, Ş., \& Kocabaş, M. (2010). Fecundity and egg size of three salmonid species (Oncorhyncus mykis, Salmo labrax, Salvelinus fontinalis) cultured at the same farm condition in North-Eastern, Turkey. Journal of Animal and Veterinary Advances, 9, 576-580.

Simopoulos A.P. (2016). An increase in the omega-6/omega-3 fatty acid ratio increases the risk for obesity. Nutrients, 8, 128.

Suyama, M. (1958). Changes in the Amino Acid Composition of Protein during the Development of Rainbow Trout Eggs, Bulletin of the Japanese Society of Scientific Fisheries. 23, 12.

Swanson, D., Block, R., \& Mousa S.A. (2012). Omega-3 fatty acids EPA and DHA: Health benefits throughout life. Advances in Nutrition, 3, 1-7.

Takeuchi, M., Ishii, S., \& Ogiso, T. (1981). Effect of dietary vitamin $E$ on growth, vitamin $E$ distribution, and mortalities of the fertilized eggs and fry in ayu 
Plecoglossus altivelis. Bulletin Tokai Regional Fisheries Research Laboratory, 104, 111-121.

Thorsen, A., Trippel, E.A., \& Lambert, Y. (2003). Experimental methods to monitor the production and quality of eggs of captive marine fish. Journal of Northwest Atlantic Fishery Science, 33, 55-70.

Tocher, D.R. (2010). Fatty acid requirements in ontogeny of marine and freshwater fish. Aquaculture Research, 41, 717-732.

Thorn, M.W., Dick, M.F., Oviedo, L., Guglielmo, C.G., \& Morbey, Y.E. (2019). Transgenerational effects of egg nutrients on the early development of Chinook salmon (Oncorhynchus tshawytscha) across a thermal gradient. Canadian Journal of Fisheries and Aquatic Sciences, 76(8), 1253-1262.

Tveiten, H., Jobling, M., \& Andreassen, I. (2004). Influence of egg lipids and fatty acids on egg viability and their utilization during embryonic development of spotted wolfish Anahichas minor Olafsen. Aquaculture Research, 35, 152-161.

Usydus, Z., Szlinder-Richert, J., Adamczyk, M., \& Szatkowska, U. (2011). Marine and farmed fish in the Polish market: Comparison of the nutritional value. Food Chemistry, $126,78-84$.
Vakili, R., \& Majidzadeh Heravi, R. (2016). Performance and egg quality of laying hens fed diets supplemented with herbal extracts and flaxseed. Poultry Science, 4, 107-116.

Watanabe, T., Fujimura, T., Lee, M.J., Fukusho, K., Satoh, S., \& Takeuchi, T. (1984). Effect of polar and nopolar lipids from krill on quality of egs of red sea bream Pagrus major. Nippon Suisan Gakkaishi, 57, 695-698.

Watanabe, T., \& Kiron, V. (1995). In: Broodstock management and egg and larval quality. pp. 398-413. Edited by N.R. Bromage and R.J. Roberts. Blackwell Science, Oxford.

Wu, T.H., \& Bechtel, P.J. (2008). Salmon by-product storage and oil extraction. Food Chemistry, 111, 868-871.

Yanes-Roca, C., Rhody, N., Nystrom, M., \& Main, K.L. (2009). Effects of fatty acid composition and spawning season patterns on egg quality and larval survival in common snook (Centropomus undecimalis). Aquaculture, 287, 335-340.

Yeşilayer, N., \& Türk, E. (2018). Determination of fatty acid compositions in eggs of commercial aquafeed fed broodstocks rainbow trout (Oncorhynchus mykiss) and brown trout (Salmo trutta spp.). Journal of New Results in Science, 7(3), 67-74. 